\title{
Update: Follow-up study showing post-pandemic decline in hand sanitiser use, New Zealand, December 2009
}

S Manning ${ }^{1}$, T Barry' ${ }^{1}$ N Wilson'1, M G Baker (michael.baker@otago.ac.nc)1

1. Department of Public Health, University of Otago, Wellington, New Zealand

Citation style for this article:

Citation style for this article: Manning S, Barry T, Wilson N, Baker MG. Update: Follow-up study showing post-pandemic decline in hand sanitiser use, New Zealand, December 2009. Euro Surveill. 2010;15(3):pii=19466. Available online: http://www.eurosurveillance.org/ViewArticle.aspx?Articleld=19466

This article has been published on 21 January 2010

This study aimed to measure rates of hand sanitiser use in a hospital entrance foyer four months after a baseline study during New Zealand's influenza pandemic. Of the 743 people observed over one (summer) day in December 2009, 8.2\% used the hand sanitiser, which was significantly lower ( $p<0.0001)$ than the $18.0 \%$ reported in the August (winter) study. Health authorities may need to intensify promotion of hand hygiene to reduce the impact of future influenza pandemic waves.

We previously published in Eurosurveillance an observational study on hand sanitiser use during the influenza $A\left(\mathrm{H}_{1} \mathrm{~N}_{1}\right)$ pandemic in the southern hemisphere winter of 2009 [1]. This study was on the public and hospital workers using a hand sanitiser station in the entrance foyer to the major hospital in New Zealand's capital city. Pandemic activity in this country subsequently declined dramatically [2-3], and there was very little media coverage of the pandemic during the spring and start of summer. The previous study was limited in that there was no pre-pandemic baseline data for hand sanitiser use by the public in New Zealand (NZ), and the extent to which hand hygiene behaviours have persisted in the post-pandemic period is unknown. Yet these behaviours are relevant given

\section{TABLE}

Hand sanitiser use in a hospital foyer entrance during summer, compared with the key results from a study in winter, New Zealand, December 2009

\begin{tabular}{|c|c|c|c|c|c|c|}
\hline \multirow{3}{*}{ Characteristics } & \multicolumn{4}{|c|}{$\begin{array}{l}\text { Follow-up study in summer } \\
\text { (December 2009) }\end{array}$} & \multirow{2}{*}{\multicolumn{2}{|c|}{$\begin{array}{l}\text { Initial study in winter } \\
\text { (August 2009) [1] } \\
\text { Used hand sanitiser }\end{array}$}} \\
\hline & \multirow{2}{*}{$\begin{array}{l}\text { Walked near hand sanitiser } \\
\text { station (number) }\end{array}$} & \multicolumn{3}{|c|}{ Used hand sanitiser } & & \\
\hline & & Number & $\begin{array}{l}\% \text { usage } \\
(95 \% \mathrm{Cl})\end{array}$ & $\begin{array}{l}\text { Risk ratio } \\
(95 \% \mathrm{CI})\end{array}$ & $\begin{array}{l}\% \text { usage } \\
(95 \% \mathrm{Cl})\end{array}$ & $\begin{array}{l}\text { Risk ratio } \\
(95 \% \mathrm{Cl})\end{array}$ \\
\hline All observations & 743 & & $\begin{array}{c}8.2 \\
(6.4-10.4)\end{array}$ & - & $\begin{array}{c}18.0 \\
(16.6-9.6)\end{array}$ & - \\
\hline \multicolumn{7}{|l|}{ Direction of movement } \\
\hline Entering the hospital & 317 & 42 & 13.2 & $3.0(1.8-5.2)$ & 20.1 & $4.8(2.8-8.1)$ \\
\hline Leaving the hospital & 411 & 18 & 4.4 & Reference (1.0) & 4.6 & Reference (1.0) \\
\hline Unclear "milling around" & 15 & 1 & 6.7 & - & - & - \\
\hline \multicolumn{7}{|l|}{ Sex } \\
\hline Female & 425 & 46 & 10.8 & $2.3(1.3-4.0)$ & 14.2 & Reference (1.0) \\
\hline Male & 318 & 15 & 4.7 & Reference (1.0) & 15 & $1.1(0.7-1.5)$ \\
\hline \multicolumn{7}{|l|}{ Age-group } \\
\hline $\begin{array}{l}\text { Children/teenagers combined } \\
\text { ( } \leq 18 \text { years) }\end{array}$ & 27 & 5 & 18.5 & $2.4(1.03-5.43)$ & 0 & $\begin{array}{l}\text { Undefined (but signifi- } \\
\text { cantly lower, } p=0.031 \text { ). }\end{array}$ \\
\hline Adults ( $>18$ years) & 716 & 56 & 7.8 & Reference (1.0) & 15.1 & Reference (1.0) \\
\hline \multicolumn{7}{|l|}{ Time of day } \\
\hline Morning (8.30-9.00) & 172 & 29 & 16.9 & $2.9(1.6-5.2)$ & 12.8 & $1.09(0.6-1.7)$ \\
\hline Midday (12.50-13.20) & 294 & 16 & 5.4 & $0.9(0.5-1.8)$ & 17.5 & $1.4(0.9-2.1)$ \\
\hline Afternoon (13.50-16.20) & 277 & 16 & 5.8 & Reference (1.0) & 12.6 & Reference (1.0) \\
\hline
\end{tabular}

$\mathrm{Cl}$ : confidence interval. 
that the country is anticipating future pandemic waves and planning an influenza vaccination programme and a supportive media campaign.

We repeated the same study as before [1], but for a working weekday in December 2009 (the first month of summer in NZ). Two observers (the first two authors) collected data, but inter-observer variation was not re-assessed as the previous study had shown this to be minimal. There were no apparent changes to the arrangement of the hand sanitiser station or its promotion since the initial study (despite recommendations to the relevant hospital authorities for this to be done [1]).

This follow-up study was based on 743 people observed in the hospital foyer over one day and found that the hand sanitiser was used by $8.2 \%$ ( $95 \%$ confidence interval (Cl): $6.4 \%$ to 10.4 , see Table). This proportion was significantly lower (p<0.0001) than the proportion reported in the earlier study of $18.0 \%$. Usage was also significantly higher for females than for males, and higher in the morning, while neither of these differences had been significant in the initial study. The significantly higher use by children and teenagers relative to adults contrasts with the findings in the initial study. Significantly higher usage on entering the hospital (compared with leaving) was seen in both studies.

The lower level of hand sanitiser use (from $18 \%$ to $8 \%$ ) could reflect an underlying seasonal pattern in hygiene behaviour by the public. But more likely is that there was a decline in awareness of the pandemic and associated hygiene behaviour over the four-month period between the two studies. This change could have been driven by reduced media reporting of the pandemic and lower public concern about this health threat (the pandemic was largely over by September 2009). Staff and regular hospital visitors may also have become habituated to hygiene messages and to the presence of the sanitiser and associated instructions in the foyer which may also have contributed to reduced use.

Female subjects were identified in this study as more conscientious regarding hand hygiene behaviour. The same result has been reported internationally (e.g. in a recent survey in Italy [4]) and also in a previous NZ study for both handwashing and soap use [5]. The higher hand sanitiser use by children in this follow-up study was a surprise finding and we noted that most of the children observed went to the sanitiser first and then the adults followed them. It is possible that hygiene education in schools during and since the pandemic may have contributed to this difference.

This follow-up study, and also the initial study, show that it is feasible to systematically observe hand sanitiser use in a hospital setting. However the study has limitations. The sample size was small; there may have been confounding in the observed associations with age group, sex and time of day; the single location may not be particularly representative of hand sanitising activity by the public visiting hospitals in NZ; nor are two studies sufficient to demonstrate robust trends over time. Consequently, we plan to collect more data (including seasonal data) in the future.

In the meantime, this study suggests that in-hospital use of hand hygiene facilities by the public has declined in the post-pandemic period in NZ. This change implies that health authorities may need to intensify and sustain hygiene messages in media campaigns, especially if they wish to minimise the impact of future influenza pandemic waves that are widely anticipated. Such campaigns are also likely to be beneficial in reducing rates of other infectious diseases transmitted by person-toperson contact.

\section{References}

1. Murray R, Chandler C, Clarkson Y, Wilson N, Baker M, Cunningham R, et al. Sub-optimal hand sanitiser usage in a hospital entrance during an influenza pandemic, New Zealand, August 2009. Euro Surveill. 2009;14(37):pii=19331. Available from: http://www.eurosurveillance.org/ViewArticle. aspx?Articleld=19331

2. Baker MG, Wilson N, Huang QS, Paine S, Lopez L, Bandaranayake $D$, Tobias M, et al. Pandemic influenza $A\left(\mathrm{H}_{1} \mathrm{~N}_{1}\right)$ $\mathrm{v}$ in New Zealand: the experience from April to August 2009. Euro Surveill. 2009;14(34):pii=19319. Available from: http:// www.eurosurveillance.org/ViewArticle. aspx?Articleld=19319

3. Wilson N, Mason K, Tobias M, Peacey M, Huang QS, Baker M. Interpreting Google flu trends data for pandemic $\mathrm{H}_{1} \mathrm{~N}_{1}$ influenza: the New Zealand experience. Euro Surveill. 2009;14(44)(44): pii=19386. Available from: http://www. eurosurveillance.org/ViewArticle.aspx?Articleld=19386

4. La Torre G, Di Thiene D, Cadeddu C, Ricciardi W, Boccia A. Behaviours regarding preventive measures against pandemic $\mathrm{H}_{1} \mathrm{~N}_{1}$ influenza among Italian healthcare workers, October 2009. Euro Surveill. 2009;14(49):pii: 19432. Available online: http://www.eurosurveillance.org/ViewArticle. aspx?Articleld=19432

5. Garbutt C, Simmons G, Patrick D, Miller T. The public hand hygiene practices of New Zealanders: a national survey. $\mathrm{N} \mathrm{Z}$ Med J. 2007;120(1265):U2810. 